Care: Jurnal Ilmiah Ilmu Kesehatan Vol .8, No.2, 2020, hal 159-167

Tersedia online di https://jurnal.unitri.ac.id/index.php/care

ISSN 2527-8487 (online)

ISSN 2089-4503 (cetak)

\title{
HUBUNGAN ANTARA KEMAMPUAN KOMUNIKASI ASERTIF DENGAN KEJADIAN PERILAKU AGRESIF PADA REMAJA
}

\author{
Endang Mei Yunalia ${ }^{1)}$, Sri Haryuni ${ }^{2)}$ \\ ${ }^{1), 2)}$ Prodi Ilmu Keperawatan Fakultas Ilmu Kesehatan Universitas Kadiri \\ E-mail: endang_mei@unik-kediri.ac.id
}

\begin{abstract}
Aggressive behavior is an action that aims to dominate or behave destructively by using verbal or physical strength aimed at the object. Aggressive behavior can occur at any stage of age including adolescents. Emotional development in adolescence causes adolescents to have a high desire for something, where this period is a critical period and a time of rebellion. One of the factors that influence the aggressive behavior in adolescents is the ability to carry out assertive communication. The purpose of the study was to determine the relationship between assertive communication skills and aggressive behavior in adolescents. This study used descriptive correlation design with cross sectional approach. The sample of 42 was recruited using simple random sampling in SMA 5 Kota Kediri. The result showed that there most a half respondent (40,5\%) have good assertive communication skills with moderate levels of aggressive behavior. Based on Chi Square: $\varrho$-value 0,000<0,05 it has been recognized that there is a correlation between assertive communication skills and aggressive behavior in adolescents. Based on the results of these studies it is expected that parents or the school will provide education about the importance of assertive communication and can be a role model for adolescents in behaving so that the incidence of aggressive behavior and juvenile delinquency can be reduced.
\end{abstract}

Keywords: Assetiveness communication; aggressive behavior; adolescents.

\begin{abstract}
ABSTRAK
Perilaku agresif adalah tindakan yang bertujuan untuk mendominasi atau berperilaku destruktif dengan menggunakan kekuatan verbal ataupun kekuatan fisik yang ditujukan pada objek. Perilaku agresif dapat terjadi pada setiap tahapan usia termasuk remaja. Perkembangan emosi pada masa remaja menyebabkan remaja memiliki keinginan yang tinggi terhadap sesuatu, dimana masa ini merupakan masa kritis dan masa memberontak. Salah satu faktor yang mempengaruhi munculnya perilaku agresif pada remaja adalah kemampuan dalam melakukan komunikasi asertif. Tujuan penelitian untuk mengetahui hubungan antara kemampuan komunikasi asertif dengan perilaku agresif pada remaja. Penelitian ini merupakan penelitian analitik korelasi dengan menggunakan pendekatan cross sectional. Sampel dalam penelitian ini sebanyak 42 siswa di SMA 5 Kota Kediri yang diambil dengan mengggunakan tekhnik simple random sampling. Hasil penelitian ini menunjukkan hampir dari setengah responden (40,5\%) memiliki kemampuan komunikasi asertif yang baik dengan tingkat perilaku agresif sedang. Hasil uji Chi-Square didapatkan $\varrho$-value 0,000 ( $\varrho$ $<\alpha(0,05)$, yang artinya ada hubungan antara kemampuan komunikasi asertif dengan perilaku

Cara mengutip: Yunalia, E. Mei \& Haryuni, Sri. (2020). Hubungan Antara Kemampuan Komunikasi Asertif Dengan Kejadian Perilaku Agresif Pada Remaja. Care:Jurnal Ilmiah Ilmu Kesehatan, 8(2), 159-167
\end{abstract}


agresif pada remaja. Berdasarkan hasil penelitian tersebut diharapkan bagi orangtua ataupun pihak sekolah agar memberikan edukasi tentang pentingnya komunikasi asertif dan bisa menjadi role model bagi remaja dalam berperilaku sehingga kejadian perilaku agresif dan kenakalan remaja bisa diturunkan.

Kata Kunci: Komunikasi asertif; perilaku agresif; remaja.

\section{PENDAHULUAN}

Masa remaja adalah masa dimana terjadi perubahan atau merupakan masa transisi pada individu yang ditandai dengan adanya perubahan fisik dan emosi atau psikologis. Memasuki masa remaja atau masa pubertas bagi sebagian remaja diartikan sebagai masa yang sulit dan masa yang berpengaruh pada keadaan fisik maupun psikologis remaja selanjutnya (Yunalia, 2017). Salah satu faktor yang menonjol pada masa perkembangan remaja adalah perkembangan aspek emosi. Emosi merupakan reaksi tubuh sebagai umpan balik terhadap suatu kondisi akibat munculnya suatu stimulus yang menimbulkan perubahan perilaku pada remaja (Fatchurahman, 2012).

Perubahan emosi dan perkembangan psikis dalam masa remaja menyebabkan individu menjadi ingin tahu tentang lingkungan di sekitarnya sekaligus menjadi rentan dalam membedakan baik dan buruk suatu hal, maka dari itulah masa ini disebut pula sebagai masa kritis dan masa memberontak. Salah satu akibat adanya perubahan emosi dan perkembangan psikis dalam masa ini adalah munculnya perilaku agresif pada remaja (Lutfiani, Sri, \& Setyawati, 2018). Perilaku agresif merupakan suatu luapan emosi sebagai reaksi terhadap kegagalan individu yang ditampakkan dalam pengrusakan terhadap manusia atau benda dengan unsur kesengajaan yang diekspresikan dengan katakata (verbal) dan perilaku (non verbal). Perilaku agresif merupakan permasalahan umum yang terjadi pada remaja dan dapat menyebabkan terjadinya permasalahan pada remaja yang melakukan perilaku agresif ataupun remaja yang menjadi korban (Shao, Liang, Yuan, \& Bian, 2014).

Studi yang dilakukan WHO tentang perilaku agresif dalam anak sekolah - Aged children (HBSC) untuk membandingkan prevelensi kekerasan negara didapatkan data bahwa dari 161.082 siswa terlibat tawuran yaitu sebanyak $37-69 \%$ untuk laki-laki dan 13-32\% untuk perempuan (Hall, 2012). Data KPAI menyatakan bahwa anak dan remaja yang berhadapan dengan hukum jumlahnya mengalami peningkatan. Pada tahun 2016 terdapat sejumlah 298 kasus dan diantaranya remaja melakukan perilaku kekerasan fisik. 
Jumlah ini meningkat 15\% dibandingkan dengan data pada tahun 2015 (Arofa, Hudaniah, Zulfiana, 2018). Berdasarkan data ini dapat disimpulkan bahwa kejadian perilaku agresif dengan berbagai akibatnya masih tinggi di Indonesia.

Data tentang jumlah remaja di Jawa Timur menunjukkan angka mencapai 16,19\% dari total penduduk yaitu mencapai 6.133 .053 jiwa menurut kelompok usia (Yunalia, 2017). Data di Jawa Timur juga ditemukan tentang kasus penganiayaan sebanyak 554 kasus pada tahun 2014, kasus ini lebih tinggi dari tahun sebelumnya yaitu 484 kasus (Yunalia \& Etika, 2019).

Hasil survei pendahuluan yang dilakukan pada siswa SMA 5 Kota Kediri menunjukkan bahwa dari 15 siswa, 6 diantaranya memiliki kebiasaan melakukan perilaku agresif baik secara verbal seperti mencaci, menyindir ataupun mengucapkan kata - kata kasar pada orang lain. Selain perilaku agresif secara verbal, juga melalui tindakan fisik seperti memukul ataupun menendang. Perilaku agresif ini dilakukan oleh remaja penyebabnya paling sering adalah karena orang lain tidak bisa memenuhi yang mereka inginkan. Dari perilaku agresif ini akhirnya bisa mengakibatkan siswa yang melakukan perilaku agresif dijauhi oleh teman temannya.
Perilaku agresif pada remaja bisa terjadi karena berbagai macam faktor, misalkan karena kurangnya perhatian dari orang terdekat, merasa tertekan dengan beban hidup, atau pengaruh media massa yang menunjukkan suatu peristiwa kekerasan. Sedangkan dampak dari perilaku agresif ini dapat terjadi pada pelaku maupun pada korban. Dampak ini dapat menyebabkan munculnya penyakit fisik dan gangguan psikologi serta kerugian material akibat perilaku agresif tersebut (Restu \& Yusri, 2013).

Perilaku agresif yang terjadi pada remaja, berkaitan dengan kemampuan komunikasi asertif. Komunikasi asertif merupakan usaha untuk memperjuangkan hak diri sendiri dengan tidak mengganggu hak orang lain. Komunikasi asertif berguna bagi remaja ataupun individu secara umum untuk menjaga kejujuran dalam melakukan komunikasi dan mampu untuk melakukan pengendalian diri (Abdulkarim, Zainul, \& Maryani, 2014). Ketidakmampuan remaja dalam melakukan komunikasi asertif pada akhirnya dapat menyebabkan remaja perilaku yang menyimpang, salah satu perilaku yang dapat muncul adalah perilaku agresif (Wardani, 2011). Berdasarkan fenomena di atas, peneliti tertarik melakukan penelitian yang berjudul hubungan antara 
kemampuan komunikasi asertif dengan kejadian perilaku agresif pada remaja.

\section{METODE PENELITIAN}

Penelitian ini dilakukan pada bulan April sampai dengan Mei tahun 2019 di SMA 5 Kediri, Kota Kediri. Jenis penelitian ini adalah penelitian analitik korelasional dengan menggunakan cross sectional study. Populasi dalam penelitian ini adalah siswa di SMA 5 Kota Kediri kelas XI, dengan sampel berjumlah 42 responden yang diambil dengan dengan menggunakan teknik simple random sampling.

Variabel dalam penelitian ini diukur dengan menggunakan kuesioner yang telah diukur validitas dan reliabilitasnya. Kuesioner digunakan untuk mengukur komunikasi asertif dan perilaku agresif. Perilaku agresif diukur dengan menggunakan Buss - Perry Aggression Questionnaire (BPAQ). Berdasarkan hasil analisis instrument, didapat nilai koefisien alpha cronbach 0,852 yang berarti instrume reliable dan uji validitas menunjukkan angka $\mathrm{r}$ table 0,1956 yang berarti intrumen valid. Analisis data dalam penelitian ini adalah analisis data univariat dan bivariat. Data komunikasi asertif diperoleh dengan menggunakan instrument Assertiveness Scale for Adolescents (ASA), dimana pada instrument ini diperoleh nilai product moment sebesar 0,798 sehingga item pertanyaan dinyatakan valid, sedangkan dari hasil uji reliabilitas diperoleh nilai $\mathrm{r}$ table 0,444 sehingga dinyatakan instrument reliable. Data bivariat dianalisis menggunakan uji statistik uji korelasi ChiSquare dengan tingkat kemaknaan $\alpha=0,05$. Setelah mendapat surat keterangan laik etik (No.28/EC/KEPK-UNIK/10/2018), dan mendapatkan persetujuan dari tempat penelitian, peneliti memulai pelaksanaan penelitian dengan member lembar inform consent kepada calon responden dan selanjutnya memberikan instrumen BPAQ dan instrument ASA.

\section{HASIL}

Berdasarkan Tabel 1 diketahui bahwa sebagian besar responden adalah perempuan (66,7\%), sebagian besar (59,5\%) responden memiliki jumlah saudara 2-3 saudara dan hampir seluruhnya responden tinggal dengan orang tua $(80,9 \%)$.

Tabel 1. Tabel distribusi frekuensi karakteristik responden

\begin{tabular}{lcc}
\hline \multirow{2}{*}{ Variabel } & \multicolumn{2}{c}{ Total } \\
\cline { 2 - 3 } & $\mathrm{f}$ & $(\%)$ \\
\hline \hline Jenis Kelamin & & \\
Laki - laki & 14 & 33,1 \\
Perempuan & 28 & 66,7 \\
\hline \hline Jumlah Saudara & & \\
Anak tunggal & 9 & 21,4 \\
2-3 saudara & 25 & 59,5 \\
$>3$ saudara & 8 & 19,1 \\
\hline \hline Tempat Tinggal & & \\
Bersama orangtua & 34 & 80,9 \\
Tidak bersama orangtua & & \\
& 8 & 19,1 \\
\hline
\end{tabular}


Berdasarkan Tabel 2 diketahui bahwa sebagian besar $(40,5 \%)$ orangtua responden sebagai petani, setengahnya (50\%) usia orang tua responden adalah lansia awal, dan pendidikan orang tua responden adalah sekolah Menengah (69\%).
Tabel 2. Tabel distribusi frekuensi karakteristik orangtua responden

\begin{tabular}{lcc}
\hline \hline Variabel & $\mathbf{f}$ & $\mathbf{( \% )}$ \\
\hline \hline Pekerjaan orangtua & & \\
Petani & 17 & 40,5 \\
Wiraswasta & 9 & 21,5 \\
Swasta & 11 & 26,1 \\
PNS & 5 & 11,9 \\
\hline \hline Usia Orangtua & & \\
Dewasa awal & 0 & 0 \\
Dewasa akhir & 8 & 19 \\
Lansia awal & 21 & 50 \\
Lansia akhir & 11 & 26,2 \\
Manula & 2 & 4,8 \\
\hline \hline Pendidikan Orangtua & & \\
Dasar & 4 & 9,6 \\
Menengah & 29 & 69 \\
Tinggi & 9 & 21,4 \\
\hline
\end{tabular}

Tabel 3. Hubungan Antara Kemampuan Komunikasi Asertif dengan Kejadian Perilaku Agresif

\begin{tabular}{|c|c|c|c|c|c|c|c|c|c|c|c|c|}
\hline \multirow{3}{*}{$\begin{array}{c}\text { Komunikasi } \\
\text { Asertif }\end{array}$} & \multicolumn{10}{|c|}{ Perilaku Agresif } & \multirow{2}{*}{\multicolumn{2}{|c|}{ Total }} \\
\hline & \multicolumn{2}{|c|}{$\begin{array}{l}\text { Sangat } \\
\text { rendah }\end{array}$} & \multicolumn{2}{|c|}{ Rendah } & \multicolumn{2}{|c|}{ Sedang } & \multicolumn{2}{|c|}{ Tinggi } & \multicolumn{2}{|c|}{$\begin{array}{c}\text { Sangat } \\
\text { tinggi }\end{array}$} & & \\
\hline & $\mathrm{f}$ & $\%$ & $\mathrm{f}$ & $\%$ & $\mathrm{f}$ & $\%$ & $\mathrm{f}$ & $\%$ & $\mathrm{f}$ & $\%$ & $\mathrm{f}$ & $\%$ \\
\hline Baik & 4 & 9,5 & 17 & 40,5 & 2 & 4,8 & 0 & 0 & 0 & 0 & 23 & 54,8 \\
\hline Sedang & 2 & 4,8 & 5 & 11,9 & 9 & 21,4 & 0 & 0 & 0 & 0 & 16 & 38,1 \\
\hline Kurang & 0 & 0 & 0 & 0 & 3 & 3 & 0 & 0 & 0 & 0 & 3 & 7,1 \\
\hline Total & 6 & 14,3 & 22 & 52,4 & 14 & 33,3 & 0 & 0 & 0 & 0 & 42 & 100 \\
\hline \multicolumn{4}{|c|}{ Correlation Coefficient $=-0,524$} & \multicolumn{4}{|c|}{ Sig. (2-tailed) $=0,000$} & & \multicolumn{2}{|c|}{$\alpha=0,05$} & & \\
\hline
\end{tabular}

Berdasarkan Tabel 3 menunjukkan bahwa hampir dari setengah responden yaitu sebanyak 17 responden (40,5\%) memiliki kemampuan komunikasi asertif baik dengan tingkat perilaku agresif yang rendah. Berdasarkan uji Chi-Square didapatkan $\varrho^{-}$ value 0,000 yang berarti $\varrho<\alpha(0,05)$, yang artinya $\mathrm{Ho}$ ditolak dan $\mathrm{H}_{1}$ diterima berarti ada hubungan antara kemampuan komunikasi asertif dengan perilaku agresif pada remaja.

\section{PEMBAHASAN}

Hasil penelitian di atas menunjukkan bahwa terdapat hubungan antara kemampuan komunikasi asertif dengan perilaku agresif pada remaja, dengan nilai signifikansi 0,000 dan angka koefisien korelasi sebesar -0,524 berarti terdapat kekuatan hubungan sedang dengan arah hubungan yang bersifat negatif dan memiliki arah negative yang berarti semakin tinggi kemampuan komunikasi asertif pada remaja, tingkat perilaku agresif semakin rendah. 
Hasil penelitian ini sesuai dengan penelitian yang dilakukan oleh Nugroho dan Diana yang menyatakan bahwa remaja yang memiliki kemampuan dalam melakukan komunikasi ataupun perilaku asertif lebih mampu bekerja sama dengan baik, memiliki tingkat sensitivitas yang cukup tinggi sehingga bisa memahami kondisi yang ada di sekitarnya dan lebih mudah melakukan adaptasi. Selain itu dengan adanya kemampuan komunikasi asertif remaja dapat melakukan aktivitasnya atau menyampaikan keinginannya dengan lebih terarah, strategis dan terkendali (Nugroho \& Diana, 2012).

Hasil penelitian lain juga menjelaskan bahwa dengan diberikannya latihan komunikasi asertif pada remaja sehingga kemampuan komunikasi asertif remaja dapat meningkat, maka tingkat perilaku agresif remaja semakin bekurang. Ini artinya terdapat korelasi antara kemampuan komunikasi asertif dengan perilaku agresif. Kemampuan melakukan komunikasi asertif juga membantu remaja agar diterima dalam kehidupan sosial, menurunkan sikap agresif, dan meningkatkan kejujuran dalam bersikap (Sari \& Idriansari, 2015).

Penelitian lain menunjukkan bahwa ketika tingkat asertivitas remaja mengalami penurunan, maka kenakalan remaja yang berkaitan dengan perilaku agresif akan meningkat. Remaja yang memiliki tingkat asertivitas yang rendah akan mudah terbawa dalam pengaruh perilaku yang negatif. Selain itu semakin tinggi kemampuan asertivitas remaja juga dapat menjadikan remaja bisa menjaga kejujuran dalam melakukan komunikasi, meningkatkan kemampuan dalam mengambil keputusan dan mampu mengendalikan diri sehingga remaja tidak melakukan perilaku agresif (Abdulkarim, Zainul, \& Maryani, 2014).

Komunikasi asertif adalah kemampuan untuk menyampaikan apa yang diinginkan, diharapkan, atau yang difikirkan oleh seseorang kepada orang lain dengan tetap menghargai perasaan dan hak orang lain (Azhari, 2017). Dengan melakukan komunikasi asertif, maka seorang remaja dapat menjalin hubungan interpersonal dengan orang lain tanpa melakukan penolakan pada dirinya sendiri ataupun pada orang lain. Perilaku ataupun komunikasi asertif. Kemampuan melakukan komunikasi asertif sangat penting bagi remaja, terutama pada tahap remaja awal agar remaja diterima dalam kelompok teman sebaya sehingga remaja tetap mendapatkan penerimaan dari lingkungannya (Wardani, 2011).

Hasil penelitian ini yang menyatakan bahwa terdapat hubungan antara kemampuan komunikasi asertif dengan perilaku agresif 
pada remaja juga sejalan dengan hasil penelitian yang dilakukan oleh Wardani yang menyatakan bahwa semakin tinggi tingkat asertivitas remaja, maka tingkat kenakalan remaja akan menurun. Dimana, kenakalan remaja ini merupakan salah bentuk dari perilaku agresif. Remaja yang mampu untuk emlakukan komunikasi asertif juga dapat terhindar dari perilaku menyimpang karena remaja dapat menyampaikan apa yang mereka harapkan tanpa menyakiti perasaan siapapun (Wardani, 2011).

Data dari hasil penelitian menunjukkan bahwa terdapat 17 responden atau hampir dari separuh responden $(40,5 \%)$ yang memiliki kemampuan komunikasi asertif baik dengan tingkat perilaku agresif yang rendah sedangkan hampir separuh responden lainnya memiliki kemampuan komunikasi asertif sedang dengan tingkat perilaku agresif yang bervariasi. Selain itu, data hasil penelitian menunjukkan sebagian kecil responden yang memiliki kemampuan komunikasi asertif yang baik memiliki tingkat perilaku agresif sedang. Ini artinya, kemampuan komunikasi asertif dan perilaku agresif pada remaja banyak dipengaruhi oleh faktor.

Salah satu yang mempengaruhi kemampuan komunikasi asertif ataupun perilaku agresif faktor keluarga. Perilaku agresif pada remaja memiliki sifat psikologis, interpersonal dan cultural. Individu atau remaja merupakan pemeran utama dalam menunjukkan eksistensinya apakah remaja akan membentuk karakter agresif, asertif, ataukah pasif dan hal ini berkaitan dengan pendidikan yang mereka dapatkan dari keluarga (Ardebili \& Golshani, 2016). Keluarga memiliki peran yang sangat penting dalam membentuk perkembangan psikologis dan social remaja. Interaksi, pola asuh dan komunikasi yang dilakukan oleh orangtua dan anak memberikan dasar kehidupan emosi pada remaja yang berpengaruh terhadap pencapaian tugas perkembangan selanjutnya.

Hasil penelitian ini menunjukkan data bahwa hampir dari separuh responden yang tidak tinggal bersama orang tua memiliki tingkat perilaku agresif sedang dan kemampuan komunikasi asertif sedang. Hal ini bisa terjadi karena kurangnya figure atau model bagi remaja dalam dalam mengelola emosi sehingga mereka menggunakan model model yang sering mereka temukan dalam mengelola emosi (Abdulkarim et al., 2014a). sehingga peneliti berasumsi bahwa remaja yang tidak tinggal bersama orang tua kemungkinan memiliki kecenderungan memiliki keampuan komunikasi asertif yang lebih rendah dibandingkan dengan remaja yang tinggal bersama orangtua. Namun hal 
ini tentunya masih memerlukan penelitian lebih lanjut.

Selanjutnya, berkaitan dengan jenis kelamin atau gender, perilaku agresif lebih banyak dilakukan pada remaja laki - laki dibandingkan remaja perempuan. Hal ini sejalan dengan hasil penelitian lain yang menyatakan bahwa secara umum laki - laki memiliki keterlibatan dalam melakukan perilaku agresif baik agresif fisik maupun verbal dibandingkan dengan remaja perempuan salah satu penyebabnya adalah remaja laki - laki lebih sering mendapatkan perlakuan yang keras dari orang tua terutama pada aspek fisik dibadingkan dengan remaja perempuan. Sehingga ketika remaja mendapatkan perilaku yang kasar, maka anak akan meniru dan menerapkan pola dalam keluarga dalam kehidupan sosialnya kemudian timbullah perilaku agresif dan remaja laki - laki akhirnya akan menarik diri dari komunikasi, dan pada akhirnya akan menghambat terbentuknya kemampuan melakukan komunikai asertif (Diana Berlianti, Aida Vitayala, Dwi Hastuti, Sarwititi Sarwoprasodjo, 2016).

Berkaitan dengan kemampuan komunikasi asertif, hasil penelitian ini menunjukkan hasil bahwa lebih dari separuh responden perempuan memiliki komunikasi asertif yang baik dibandingkan remaja laki - laki. Namun hal ini tidak sejalan dengan teori yang menyatakan bahwa remaja laki - laki cenderung lebih mampu untuk melakukan komunikasi asertif karena sejak kecil anak laki - laki dibiasakan untuk berperilaku tegas dan asertif dibandingkan anak perempuan. Anak perempuan cenderung lebih tampak pasif dalam mengngkapkan perasaan terutama dengan hal yang berkaitan dengan apa yang menjadi harapannya (Ninawati, 2012). Peneliti berasumsi bahwa kemampuan komunikasi asertif selain dipengaruhi oleh aspek gender, ada faktor eksternal lain yang juga berpengaruh, terutama teman sebaya. Sebagaimana sesuai dengan tahap perkembangannya, bahwa remaja cenderung mengadaptasi perilaku yang dia dapatkan dari peer group maupun teman sebaya.

\section{KESIMPULAN}

Hampir dari setengah responden memiliki kemampuan melakukan komunikasi asertif yang baik dengan tingkat perilaku agresif yang rendah dan terdapat hubungan antara kemampuan komunikasi asertif dengan perilaku agresif pada remaja.

\section{REFERENSI}

Abdulkarim, A., Zainul, A., \& Maryani, E. (2014a). Perilaku Asertif dan Kecenderungan Kenakalan Remaja Berdasarkan Pola Asuh dan Peran Media Massa, 41(1), 74-88.

Abdulkarim, A., Zainul, A., \& Maryani, E. (2014b). Perilaku Asertif dan 
Kecenderungan Kenakalan Remaja Berdasarkan Pola Asuh dan Peran Media Massa. Jurnal Psikologi, 41(1), 7488.

Ardebili, E. F., \& Golshani, F. (2016). Early Maladaptive Schemas and Aggression Based on the Birth Order of Children. Modern Applied Science, 10(9), 14-21. https://doi.org/10.5539/mas.v10n9p1 4

Arofa, I. Z., Hudaniah, \& Zulfiana, U. (2018). Pengaruh Perilaku Bullying terhadap Empati Ditinjau dari Tipe Sekolah. Jurnal Imiah Psikologi Terapan, 06(01), 74-92.

Azhari, H. (2017). Gaya Komunikasi Dalam Menanggulangi Penyalahgunaan Narkoba di Kalangan Remaja Muslim Kelurahan Gading Kecamatan Datuk Bandar Kota Tanjungbalai.

Diana Berlianti, Aida Vitayala, Dwi Hastuti, Sarwititi Sarwoprasodjo, D. K. (2016). What 's with Parent-Adolescent Communication? Effects on Adolescent' s Aggresiveness Toward Others. Jurnal Ilmu Keluarga Dan Konseling, 9(3), 183-194.

Fatchurahman, M. (2012). Kepercayaan Diri, Kematangan Emosi, Pola Asuh Orang Tua Demokratis dan Kenakalan Remaja. Persona-Jurnal Psikologi Indonesia, 1(2), 77-87.

Hall, C. M. F. (2012). Understanding aggressive behaviour across the lifespan.

https://doi.org/10.1111/j.13652850.2012.01902.x

Lutfiani, D., Sri, \& Setyawati, P. (2018). Hubungan Antara Kecerdasan Emosional dengan Perilaku Agresif Siswa kelas VIII SMP Negeri 8 Kediri Tahun Ajaran 2017/ 2018. SimkiPedagogia, 02(03).
Ninawati, T. M. (2012). Training Komunikasi Asertif Untuk Mengingkatkan Perilaku Asertif Terhadap Keterampilan kerjasama Pada Pre Operational First Officer PT.X.

Nugroho, S., \& Diana, J. (2012). Studi Komparasi Tingkat Asertifitas Pada Mahasiswa Pg-Paud Di Universitas. Jurnal Visi Ilmu Pendidikan, 1469-1479.

Restu, Y., \& Yusri. (2013). Studi tentang Perilaku Agresif Siswa di Sekolah. Jurnal Ilmiah Konseling, 2(1), 243-249.

Sari, P. A., \& Idriansari, A. (2015). Pengaruh Latihan Asertif Terhadap Penurunan Perilaku Agresif Pada Laki- Laki Usia Remaja Awal yang Bermain Game Online Jenis Agresi di SMP Negeri 2 OKU. Jurnal Kedokteran Dan Kesehatan, 2(2), 183-189.

Shao, A., Liang, L., Yuan, C., \& Bian, Y. (2014). A Latent Class Analysis of Bullies , Victims and Aggressive Victims in Chinese Adolescence : Relations with Social and School Adjustments. Plos One, 9(4). https://doi.org/10.1371/journal.pone. 0095290

Wardani, D. K. (2011). HUBUNGAN PERILAKU ASERTIF DENGAN KENAKALAN REMAJA PADA SISWA KELAS XI SMA BHAKTI PRAJA KABUPATEN BATANG TAHUN AJARAN 2009 / 2010.

Yunalia, E. M. (2017). Hubungan antara Konsep Diri dengan Penerimaan Perubahan Fisik Remaja Putri pada Masa Pubertas. Nursing Science Jurnal, 1, 30-36.

Yunalia, E. M., \& Etika, A. N. (2019). Efektivitas Terapi Kelompok Assertiveness Training terhadap Kemampuan Komunikasi Asertif pada Remaja dengan Perilaku Agresif. Jurnal Keperawatan Jiwa, 7(3), 229-236. 